\title{
MANFAAT PROGRAM PENDIDIKAN INKLUSI UNTUK AUD
}

\author{
Nurul Kusuma Dewi \\ PG PAUD Universitas Sebelas Maret \\ Kusuma.Dewi@Staff.Uns.Ac.Id
}

\begin{abstract}
Abstrak
Tujuan penelitian ini untuk mengetahui manfaat penerapan program pendidikan inklusi untuk anak usia dini. Penelitian dilaksanakan di Labschool Rumah Citta Yogyakarta pada bulan April-Juni 2016. Penelitian ini menggunakan pendekatan kualitatif dengan jenis penelitian studi kasus. Subyek penelitian adalah murid Labschool Rumah Citta dari usia 2-7 tahun. Teknik pengumpulan data dengan wawancara, observasi, dan dokumentasi.teknik analisis data menggunakan model interaktif Miles dan Humberman. Hasil penelitian menunjukan bahwa program pendidikan inklusi yang diterapkan di Labschool Rumah Citta memberikan manfaat baik bagi anak yang memiliki kebutuhan khusus mapupun anak normal pada umumnya. Penerapan program pendidikan inklusi di Labschool Rumah Citta dapat menstimulasi perkembangan dan menanamkan nilai karakter pada anak, yaitu: (1) anak mau saling membantu dan bermain bersama dengan anak berkebutuhan khusus; (2) anak dapat mengenal dan menghargai perbedaan; (3) anak memiliki tanggung jawab dan rasa percaya diri; dan (4) anak memiliki keterampilan sosial.
\end{abstract}

Kata Kunci: Program Pendidikan Inklusi; AUD

\section{THE BENEFITS OF INCLUSIVE EDUCATIONAL PROGRAMME FOR EARLY CHILDHOOD}

\begin{abstract}
The purpose of this study to determine the benefits of the implementation of inclusive education programs in early childhood (Early Childhood Education). The research was conducted at Labschool Rumah Citta Yogyakarta in April-June 2016. This research used qualitative approach with research case study type. The subjects of the study were students of Labschool Rumah Citta from the age of 2-7 years. Data collection techniques with interviews, observation, and documentation. Data analysis techniques using interactive models Miles and Humberman. The results showed that the inclusion education program implemented at Labschool Rumah Citta provides benefits for children with special needs and normal children. Implementation of inclusion education program at Labschool Rumah Citta can stimulate development and instill character value in children, namely: (1) children want to help each other and play together with children with special needs; (2) children can recognize and appreciate differences; (3) the child has responsibility and confidence; And (4) children have social skills.
\end{abstract}

\section{Keywords: Inclusive Education Program; Early Childhood}

\section{PENDAHULUAN}

Fenomena pendidikan untuk semua tidak hanya diperuntukan bagi anak-anak yang memiliki kebutuhan khusus tapi bagi semua anak untuk mendapat kesempatan dan pelayanan pendidikan yang layak. Program pendidikan inklusi menjadi salah satu program pendidikan untuk mencapai tujuan nasional pendidikan. Indonesia merupakan negara yang kaya akan sumber daya alam dan budaya, tapi hal ini belum sepenuhnya mendukung terlaksanya pendidikan yang layak bagi semua anak. Program pemerintak akan pentingnya 
pendidikan belum sepenuhnya didukung oleh pelaksanaan di lapangan. Realita di lapangan menunjukan bahwa pendidikan masih terkotak-kotak berdasarkan wilayah, agama, kebutuhan khusus, budaya, dsb. Kesempatan dan kemerataan pedidikan nasional belum sepenuhkan menjangkau dan memfasilitasi semua anak Indonesia.

Program pendidikan inklusi sudah diterapkan berorientasi terhadap pelayanan kepada anak, sehingga kebutuhan setiap anak terpenuhi. Program pendidikan inklusi tidak hanya diterapkan pada anak yang memiliki kebutuhan khusus tetapi untuk semua anak karena pada dasarnya setiap anak memiliki karakteristik, keunikan, dan keberagamaan secara alamiah sudah ada pada diri anak. Karakteristik setiap anak ini yang harus difasilitasi dalam semua jenjang pendidikan pada umumnya dan pendidikan anak usia dini pada khususnya. Undang-Undang Nomor 20 tahun 2003 tentang sistem pendidikan nasional yang mengatur setiap warga negara mempunyai hak yang sama untuk mendapatkan pendidikan dasar yang bermutu baik yang mengalami kelainan fisik, mental, emosional, intelektual, memiliki bakat istimewa, dan yang tinggal di daerah terpencil. Undang-Undang tentang sitem pendidikan ini menjelaskan bahwa pendidikan inkusi tidak hanya untuk anak-anak yang mengalami kebutuhan secara fisik tetapi juga untuk anak-anak yang mempunyai kebudayaan, sosial, geografi dan bahasa yang berbeda untuk mendapatkan layanan pendidikan yang sama sesuai kebutuhan setiap anak sehingga dapat menstimulai perkembangan, pengetahuan dan keterampilan anak.

Kondisi di lapangan masih banyak sekolah-sekolah pada umumnya dan PAUD pada khususnya untuk melaksanakan program pendidikan inklusi. Selain ketidaksiapan sumber daya manusia dan sarana prasarana, ketidaktahuan tentang tujuan dan manfaat yang diperoleh anak baik anak normal maupun anak yang memiliki kebutuhan. Pelaksanaan pendidikan di lapangan cenderung menilai bahwa jika anak berkebutuhan khusus diberikan pelayanan pendidikan yang sama dan bersamaan dengan anak normal maka hanya akan mengganggu proses pendidikan dan pengaruh tidak baik pada anak normal. Pola pendidikan seperti ini akan membawa dampak pada anak baik anak berkebutuhan khusus maupun anak normal, yaitu apatis, tidak menghormati, tidak percaya diri, individualisme, dan tidak siap hidup dimasyarakat. Padahal program pendidikan inklusi ini memberikan pendidikan tentang nilai perbedaan dan keberagamaan sehingga anak-anak akan saling menghormati dan membantu satu sama lain sebagai bekal menghadapi kehidupan bermasyarakat. Hal ini sesuai dengan konsep negara Indonesia, yaitu memiliki berbagai keberagaman budaya, bahasa, sosial, geografi, agama, dsb. Semua itu yang harus kita ajarkan kepada anak usia dini secara konkret melalui program pendidikan inklusi.

\section{Tujuan dan Manfaat Program Pendidikan Inklusi}

Pendidikan inklusi merupakan
konsep pendidikan merepresentasikan seluruh aspek yang berkaitan dengan keterbukaan dalam menerima anak berkebutuhan khusus untuk memperoleh hak dasar sebagai warga negara serta dapat menjadi strategi dalam mempromosikan pendidikan universal yang efektif karena dapat menciptakan sekolah yang responsif terhadap beragam kebutuhan aktual dari anak dan masyarakat (Ilahi, 2013: 24). Pendidikan inklusi menjadi salah satu solusi dalam dunia pendidikan untuk mewujudkan pemerataan pendidikan di Indonesia. Pendidikan inklusi mencerminkan pendidikan yang diperuntukan bagi semua anak tanpa terkecuali baik keterbatasan secara mental, fisik, komunikasi, sosial maupun finansial.

Pendidikan inklusi adalah sebuah paradigma yang humanis dan falsafah 
pendidikan yang dapat mengakomodasi semua peserta didik sesuai dengan kebutuhannya, selain itu pendidikan inklusi adalah pendidikan yang tidak diskriminatif yang memberikan layanan terhadap semua peserta didik tanpa memandang kondisi fisik, mental, intelektual, sosial emosi, ekonomi, jenis kelamin, suku, budaya, tempat tinggal, bahasa, dan sebagainya (Kustawan, 2013: 12-13). Pendidikan inklusi mencerminkan tentang keberagaman yang meliputi: agama, ekonomi, budaya, gender, bahasa, dan anak berkebutuhan. Inklusi adalah mendidik anak-anak yang memiliki kebutuhan pendidikan khusus secara penuh waktu dalam kelas reguler (Santrock, 2012: 274). Pada pendidikan inklusi anak yang memiliki kebutuhan khusus mendapat pelayanan di kelas reguler dengan waktu penuh. Pelaksanaan pendidikan inklusi menurut UNESCO mestinya sekolah menerima, merawat, mendidik anak tanpa memandang perbedaan jenis kelamin, fisik, intelektual, sosial, linguistik atau karakter lainnya.

Perubahan paradigma dalam bidang pendidikan didasarkan pada pendidikan untuk semua anak. Pendidikan yang melayani, menerima, mengakui, memberikan kesempatan, dan memberikan penghargaan kepada setiap anak sesuai dengan pencapaian kemampuannya. Departemen Pendididkan Nasional mengelarkan pedoman penyelenggaraan pendidikan inklusi, yaitu penyelenggaraan pendidikan inklusif menuntut pihak sekolah melakukan penyesuaian baik dari segi kurikulum, sarana parasarana pendidikan, maupun sistem pembelajaran yang disesuaikan dengan kebutuhan individu peserta didik. Lembaga pendidikan yang melaksanakan pendidikan inklusif harus mempersiapkan diri untuk menyesuaikan dengan kebutuhan setiap individu baik kurikulum, sarana-prasaran, pembelajaran, dsb. Pendidikan inklusi dapat memberikan pelayanan pendidikan kepada semua anak yang mengalami kebutuhan dengan tidak mendiskriminasikan.

Tujuan pendidikan inklusi antara lain: (1) memberikan kesempatan yang seluas-luasnya kepada peserta didik yang memiliki kelaian fisik, sosial, emosional, mental, maupun peserta didik yang memiliki kecerdasan atau bakat istimewa untuk memperoleh pendidikan yang bermutu sesuai dengan kebutuhan dan kemampuannya; serta (2) mewujudkan penyelenggaraan pendidikan yang menghargai keanekaragaman dan tidak diskriminasi bagi semua peserta didik (Smith, 2006: 41).

Menurut pendapat Smith di atas, pendidikan inklusi bertujuan memberikan kesempatan yang seluas-luasnya dalam pendidikan kepada peserta didik yang memiliki kebutuhan tanpa diskriminasi sehingga mendapatkan pelayanan sesuai kebutuhannya dan melaksanakn pendidikan yang menekankan pada keberagaman. Dalam pelaksanaan pendidikan inklusi pihak sekolah harus melakukan penyesuaian baik dari segi kurikulum, sarana prasarana pembelajaran, sistem pembelajaran maupun lingkungan pembelajaran harus disesuaikan dengan kebutuhan individu peserta didik (anak). Pendidikan inklusi berusaha mengakomodasi segala bentuk perbedaan dari anak, memberikan penghargaan dan kesempatan serta peluang yang sama kepada setiap anak untuk mendapatkan layanan pendidikan yang layak dan berkualitas untuk mengembangkan seluruh aspek perkembangan anak.

Penyelenggaraan program pendidikan inklusi di Indonesia diatur didalam Undang-Undang. Tujuan pendidikan inklusi di Indonesia diataur oleh Departemen Pendidikan Nasional. Adapaun tujuan penyelenggaraan pendidikan inklusi di Indonesia (Depdiknas: 2009, 10-11) yaitu: (1) memberikan kesempatan yang seluas-luasnya kepada semua anak (termasuk anak berkebutuhan khusus) mendapatkan pendidikan yang layak 
sesuai dengan kebutuhannya; (2) membantu mempercepat program wajib belajar pendidikan dasar; (3) membantu meningkatkan mutu pendidikan dasar dan menengah dengan menekan angka tinggal kelas dan putus sekolah; (4) menciptakan sistem pendidikan yang menghargai keanekaragaman, tidak diskriminatif, serta ramah terhadap pembelajaran; memenuhi amanat Undang-Undang Dasar 1945 khususnya Pasal 32 ayat 1, UU no. 20 tahun 2003 khususnya Pasal 5 ayat 1, UU No. 23 Tahun 2002 tentang Perlindungan Anak, Pasal 51.

Fungsi pendidikan inklusi adalah untuk menjamin semua peserta didik berkebutuhan khusus mendapatkan kesempatan dan akses yang sama untuk memperoleh layanan pendidikan yang sesuai dengan kebutuhannya dan bermutu diberbagai jalur, jenis, dan jenjang pendidikan serta menciptakan lingkungan pendidikan yang kondusif bagi peserta didik berkebutuhan khusus untuk mengembangkan potensinya secara optimal (Kustawan, 2013: 16). Selain memiliki fungsi, pendidikan inklusi juga memberikan manfaat kepada berbagai pihak, antara lain: peserta didik berkebutuhan khusus, peserta didik pada umumnya, orang tua, guru, pemerintah, dan masyarakat. Allen dan Schwartz mengungkapakan manfaat lingkungan yang inklusif untuk anak yang memiliki kebutuhan, antara lain: (1) lebih merangsang, memiliki keberagaman dan reponsif; (2) memungkinkan perkembangan kurikulum; (3) memberikan kesempatan pada anak berkebutuhan khusus untuk berinteraksi dengan anak lain dan meningkatkan kemampuannya; serta (4) memberikan kesempatan anak berkebutuhan khusus untuk belajar akademis dari teman sebaya (Smith, 2006: 424). Manfaat pendidikan inklusi untuk peserta didik berkebutuhan khusus adalah dapat meningkatkan rasa percaya diri, memiliki kesempatan menyesuaikan diri, dan memiliki kesiapan dalam menghadapi kehidupan di masyarakat, sedangkan peserta didik pada umumnya dapat belajar mengenai keterbatasan, kelebihan, dan keunikan tertentu pada temannya sehingga dapat mengembangkan keterampilan sosial, menumbuhkan rasa empati dan simpati terhadap orang lain (Kustawan, 2013: 18).

Rasa percaya bahwa inklusi yang lebih besar dapat menghasilkan proses pengajaran dan pembelajaran yang meningkat bagi semua anak. Persahabatan antara anak dengan atau tanpa hambatan adalah sebuah norma. Sekolah memberikan dukungan sumber daya lain untuk memberikan layanan kepada anak berkebutuhan. Sekolah memberikan berbagai pelatihan pada guru untuk menangani jumlah keberagaman anak yang lebih berbeda. Kepala sekolah dan staf harus bekerjasama dalam memberikan dukungan pada implementasi pendidikan inklusi. Kurikulum yang digunakan harus cukup fleksibel. Penilaian dilakukan untuk memberi gambaran akhir tentang tentang pencapaian prestasi dan tujuan belajar setiap anak. Sistem evaluasi harus digunakan untuk menilai keberhasilan program dan staf pada pendidikan inklusi. Keterlibatan orang tua bertujuan untuk memahami rencana dalam membentuk lingkungan inklusif dan ramah bagi anak. Pihak sekolah melibatkan masyarakat dalam usaha meningkatkan keterlibatan dan penerimaan anak yang memiliki kebutuhan khusus di dalam sekolah. Dari berbagai penjabaran di atas pendidikan inklusi dapat disimpulkan sebagai suatu paradigma pendidikan yang memberikan pelayanan pada semua anak tanpa diskriminasi (membeda-bedakan), menghargai keberagaman, serta sikap menerima, mengakui, memberikan kesempatan, dan memberikan penghargaan kepada anak yang memiliki kelainan atau hambatan baik hambatan secara temporer maupun permanen untuk memenuhi kebutuhan setiap anak dan mengembangkan potensi yang dimiliki. 


\section{METODE PENELITIAN}

Penelitian ini bertujuan untuk mengetahui manfaat pelaksanaan program pendidikan inklusi untuk anak usia dini. Penelitian ini menggunakan pendekatan kualitatif dengan jenis penelitian studi kasus. Subyek penelitian adalah murid Labschool Rumah Citta. Tenik pengumpulan data pada penelitian ini adalah observasi, wawancara, dan dokumentasi. Analisis data menggunakan menggunakan model interaktif Miles dan Huberman

\section{HASIL PENELITIAN DAN PEMBAHASAN}

Anak merupakan komponen utama dalam proses pendidikan. Pada setiap program pendidikan diharapkan anak mendapatkan manfaat secara langsung maupun tidak langsung. Program pendidikan inklusi yang diterapkan pada PAUD (Pendidikan Anak Usia Dini) diharapkan dapat memberikan manfaat untuk anak. Keberhasilan pelaksanaan program pendidikan inklusi akan terlihat langsung pada anak. Hasil penelitian yang dilakukan di Labschool Rumah Citta, yaitu: anak-anak mendapat manfaat yang positif dalam setiap aspek perkembangan anak dan nilai-nilai inklusifitas. Nilai-nilai inklusifitas yang diterapkan di sekolah dapat mengenalkan dan menghargai perbedaan serta keberagaman. Pelaksanaan program inklusi juga dapat memupuk keterampilan sosial anak dan rasa percaya diri anak. Program pendidikan inklusi memberikan kesempatan pada anak untuk berinteraksi, berkomunikasi, dan beradaptasi dengan lingkungan

Program pendidikan inklusi di Labschool Rumah Citta dilaksanakan pada kegiatan bersama dan kegiatan pembelajaran. Nilai-nilai inklusif diterapkan melalui pembiasaan, sehingga anak dapat memahami dan menerapkan pada kehidupan sehari-hari. Hasil penelitian menunjukan bahwa anak-anak Labschool Rumah Citta mempunyai keterampilan sosial yang baik. Anak-anak senang membantu teman baik yang mengalami kesulitan maupun tidak, seperti: membantu teman mengambilkan pensil, membantu mengambilkan tempat minum teman, membantu guru membereskan kelas, menolong teman maupun orang dewasa yang membutuhkan bantuan. Anak-anak Labschool Rumah Citta dapat bekerjasama dalam menyelesaikan tugas kelompok atau tim dengan cara berdiskusi dan membagi tugas sehingga tugas dapat diselesaikan tepat waktu dengan cara anak sendiri. Anak-anak Labschool Rumah Citta menjadi tutor bagi anak lain baik ABK maupun biasa. Anak-anak juga mau memahami keadaan teman yang lain. Anak-anak Labschool Rumah Citta mau bermain dengan semua teman baik yang ABK maupun anak biasa. Anak-anak biasa mengajak dan memberikan kesempatan bermain bagi anak yang memiliki kebutuhan khusus. Anak-anak juga dapat bermain dalam tim atau kelompok dengan anak-anak berkebutuhan khusus. Hal ini selalu ditanamkan oleh guru untuk bermain dengan semua teman.

Anak-anak Labschool Rumah Citta dapat mengenal dan menghargai perbedaan baik perbedaan secara fisik, kemampuan, budaya, bahasa, dan agama. Anak-anak terbiasa dengan keberagaman. Anak-anak bermain dengan semua anak tanpa memilih-milih teman meskipun setiap anak punya temen dekat. Anak-anak Labschool Rumah Citta menghargai teman yang berdo'a dengan cara yang berbeda. Anak-anak mampu mengenal dan menghargai kelebihan diri sendiri dan orang lain, menghargai pendapat dan hasil karya diri sendiri serta orang lain, memberikan apresiasi bahwa semua hasil karya anak itu bagus. Guru selalu memberikan apresiasi kepada anak-anak pada setiap capaian atau hasil yang anak lakukan. Bentuk apresiasi yang diberikan berupa tepuk tangan, ucapan selamat, pelukan, dsb. Anak-anak Labschool Rumah Citta mampu menyelesaikan masalah dengan musyawarah atau diskusi (berpendapat, berkomentar, dan bertanya). 
Anak-anak senang membantu teman ABK untuk bisa melakukan sesuatu hingga berhasil. Anak mengenal dan menghargai keberagaman lingkungan. Anak-anak dapat bermain bersama dengan teman yang memiliki kebutuhan khusus, memiliki fisik yang berbeda (warna kulit, bentuk rambut, warna rambut,dsb.), memiliki agama yang berbeda (islam, kriten, katolik, hindu, budha, dsb.), budaya yang berbeda (bali, jawa, batak, dsb.), serta jenis kelamin (perempuan dan laki-laki). Anak-anak Labschool Rumah Citta memiliki rasa simpati. Hal ini terlihat ketika ada teman yang bermain sendiri anak-anak yang lain mengajak bermain bersama, ketika ada teman yang menangis anak-anak selalu bertanya "kenapa kok sedih?", anak-anak juga menanyakan kabar teman yang tidak masuk sekolah. Anak-anak Labschool Rumah Citta memiliki rasa empati. Hal ini terlihat anak-anak suka membantu teman maupun orang lain. Anak-anak akan membagi bekal makan kepada teman yang tidak membawa bekal tanpa disuruh oleh guru, anak-anak menyumbangkan mainan maupun pakaian untuk dibagikan keteman-teman yang belum beruntung (lingkungan sekitar sekolah maupun panti asuhan). Kegiatan ini rutin dilakukan setiap tahun pada kegiatan pasar murah.

Anak-anak memiliki rasa percaya diri yang tinggi dan kesiapan beradaptasi dengan lingkungan. Hal ini terlihat pada sikap anak-anak di Labschool Rumah Citta setiap hari, yaitu: (1) anak dapat mengungkapkan ide dan pendapatnya pada teman maupun guru dan dapat menerima pendapat orang lain; (2) anak dapat menyelesaikan masalah antar teman maupun dengan orang dewasa dengan cara mengungkapkan apa yang dirasakan anak; (3) anak berani menegur dan mengingatkan teman maupun orang dewasa yang tidak mengikuti kesepakatan, contoh: kesepakatan untuk antri dan bergantian; (4) anak mempunyai kesadaran diri ketika melanggar kesepakatan; (5) anak selalu berlomba-lomba untuk bercerita di depan teman-teman; (6) anak berani mengajukan pertanyaan tentang sesuatu hal; (7) anak mampu menjadi leader atau pemimpin dalam kelompok besar maupun kecil.

Pelaksanaan program pendidikan inklusi yang dilakukan oleh Labschool Rumah Citta memberikan manfaat pada anak, meliputi: (1) sekolah memberikan kesempatan yang seluas-luasnya kepada anak berkebutuhan khusus dan anak biasa untuk saling berinteraksi dan berkomunikasi dengan orang lain maupun lingkungan; (2) anak memiliki rasa percaya diri yang tinggi; (3) anak mengenal dan menghargai perbedaan, sehingga mengetahui keterbatasan dan kelebihan diri dan tidak meremehkan orang lain; (4) memiliki kerampilan sosial, yaitu anak-anak mempunyai rasa simpati dan empati, suka menolong. Anak-anak terbiasa berbagai dan bermain bersama.

Hasil penilitian program pendidikan inklusi pada pendidikan anak usia dini di Labschool Rumah Citta diperoleh kesimpulan bahwa anak-anak di Labschool Rumah Citta, baik anak ABK maupun anak biasa mempunyai rasa percaya diri yang tinggi dan mempunyai keterampilan sosial yang baik. Hal ini ditunjukan bahwa anak ABK dan anak biasa dapat bermain dan berinteraksi di dalam maupun di luar kelas. Anak-anak Labschool Rumah Citta suka menolong, terbiasa bekerjasama, dan berbagi. Anak-anak Labcshool Rumah Citta terbiasa berbagi bekal makanan pada saat istirahat makan bekal. Anak-anak Labschool Rumah Citta dapat memahami dan mengahargai keberagaman. Hal ini ditunjukan anak-anak dapat menghargai pendapat orang lain dengan mendengarkan dan menerima pendapat teman, melakukan musyawarah, tidak membeda- bedakan teman, membantu mendampingi anak berkebutuhan. Anak-anak selalu meminta maaf jika melakukan kesalahan dan memaafkan teman. Anak-anak selalu diajarkan untuk sayang teman. Manfaat yang diperoleh anak dari pelaksanaan program pendidikan inklusi di Labschool Rumah Citta tercermin dalam perilaku 
anak setiap hari. Hal ini sesuai dengan standar kriteria evaluasi program pendidikan inklusi pada pendidikan anak usia dini, yaitu: (1) anak ABK dan biasa mempuyai kesempatan untuk berinteraksi dan berkomunikasi dengan orang lain maupun lingkungan tanpa diskriminasi; (2) anak-anak Labschool Rumah Citta mempunyai keterampilan sosial; dan (3) anak-anak mengenal dan mengahargai keberagaman atau perbedaan. Hal ini disebabkan Labschool Rumah Citta konsisten dalam melaksanakan nilai-nilai inklusifitas dan bekerjasama dengan orang tua sehingga program dapat dilaksanakan secara berkesinambungan dan optimal.

Hasil penelitian di Labschool Rumah Citta membuktikan bahwa program pendidikan inklusi pada pendidikan anak usia dini memberikan dampak positif pada anak, yaitu anak memiliki keterampilan hidup, anak memiliki kesiapan untuk kejenjang pendidikan sekolah dasar, dan sikap anak memiliki nilai-nilai karakter yang baik seperti menghargai pendapat orang lain, meminta maaf, terimakasih, berbagi, dsb. Hasil penelitan sesuai dengan pendapat Kustawan (2013: 18) bahwa pendidikan inklusi bermanfaat untuk peserta didik berkebutuhan khusus adalah dapat meningkatkan rasa percaya diri, memiliki kesempatan menyesuaikan diri, dan memiliki kesiapan dalam menghadapi kehidupan di masyarakat, sedangkan peserta didik pada umumnya dapat belajar mengenai keterbatasan, kelebihan, dan keunikan tertentu pada temannya sehingga dapat mengembangkan keterampilan sosial, menumbuhkan rasa empati dan simpati terhadap orang lain. Tujuan pelaksanakan program pendidikan inklusi sejalan dengan tujuan pendidikan anak usia dini yaitu, menstimulasi perkembangan anak, menanamkan nilai-nilai, dan keterampilan hidup sehingga anak-anak memiliki kesiapan untuk melanjutkan jenjang pendidikan selanjutnya maupun untuk bekal hidup ditengah-tengah masyarakat.

Penerapan program inklusi di PAUD (Pendidikan Anak Usia Dini) memberikan manfaat bagi perkembangan anak dengan konsep Vygotsky tentang ZPD (Zona Proxymal Development) dimana aspek perkembangan anak akan mengalami peningkatan jika dibantu oleh orang lain (teman, guru, atau orang tua). Pada pelaksanaan program pendidikan inklusi di Labschool Rumah Citta, guru menggunakan teman sebaya yang perkembangannya lebih baik untuk membantu teman yang masih membutuhan stimulasi. Melibatkan anak dalam kegiatan pendidikan dan pembelajaran juga memberikan kesempatan pada anak untuk dapat membantu dan menstimulasi perkembangan anak. Kemamapuan problem solving anak juga dapat terstimulasi ketika anak menyelesaikan masalah dengan anak-anak yang memiliki kebutuhan.

Penerapan program pendidikan inklusi di PAUD dapat menjadi alternatif metode utuk penanaman nilai-nilai karakter dan nasionalis pada anak. Kelas inklusi menjadi sarana dan prasarana anak untuk mengenal perbedaan, keberagaman, dan menganalisis kebutuhan diri sendiri dan orang lain. Dengan memberikan kesempatan yang sama dan seluas-luasnya kepada anak usia dini berkebutuhan khusus (ABK) dan anak normal. Manfaat penerapan program pendidikan inklusi yang muncul di Labschool Rumah Citta baik anak berkebutuhan khusus (ABK) atau anak normal sesuai dengan pendapat Kustwan (2013: 18), yaitu: (1) untuk peserta didik berkebutuhan khusus adalah dapat meningkatkan rasa percaya diri, memiliki kesempatan menyesuaikan diri, dan memiliki kesiapan dalam menghadapi kehidupan di masyarakat; (2) peserta didik pada umumnya dapat belajar mengenai keterbatasan, kelebihan, dan keunikan tertentu pada temannya sehingga dapat mengembangkan keterampilan sosial, menumbuhkan rasa empati dan simpati terhadap orang lain. 


\section{PENUTUP}

Penerapan program pendidikan inklusi di Labschool Rumah Citta dilaksanakan dengan memberikan kesempatan yang seluas-luasnya pada anak berkebutuhan khusus (ABK) dan anak normal untuk saling berinteraksi. Aspek perkembangan anak akan saling terstimulasi dengan adanya tutor sebaya dan penanman nilai karakter dengan pembiasaan dalam pembelajaran. Penerapan pedidikan inklusi di Labschool Rumah Citta juga memberikan dampak positif pada anak, sehingga anak-anak di Labschool Rumah Citta mau saling membantu dan bermain bersama dengan anak berkebutuhan khusus; mengenal dan menghargai perbedaan; memiliki tanggung jawab dan rasa percaya diri; dan memiliki keterampilan sosial. Hal ini terlihat pada kegiatan anak-anak dalam pembelajaran, yaitu: (1) anak dapat mengungkapkan ide dan pendapatnya pada teman maupun guru dan dapat menerima pendapat orang lain; (2) anak dapat menyelesaikan masalah antar teman maupun dengan orang dewasa dengan cara mengungkapkan apa yang dirasakan anak; (3) anak berani menegur dan mengingatkan teman maupun orang dewasa yang tidak mengikuti kesepakatan, contoh: kesepakatan untuk antri dan bergantian; (4) anak mempunyai kesadaran diri ketika melanggar kesepakatan; (5) anak selalu berlomba-lomba untuk bercerita di depan teman-teman; (6) anak berani mengajukan pertanyaan tentang sesuatu hal; (7) anak mampu menjadi leader atau pemimpin dalam kelompok besar maupun kecil

\section{DAFTAR PUSTAKA}

Depdiknas. (2009).
LIRP-Merangkul Tulkit
Perangkat untuk Pengembangan
Inklusif Ramah terhadap
Pembelajaran, Buku Khusus 3:
Mengajar Anak-Anak dengan
Disabilitas dalam Setting Inklusif.
Jakarta: IDPN Indonesia,
Arbeiter-Samariter-Bund, Handicap
International, Plan Indonesia.

Ilahi, M. T. (2013). Pendidikan Inklusi: Konsep dan aplikasi. Yogyakarta: Ar-Ruzz Media.

Kemdikbud. (2003). UU No.20 Tahun 2003 tentang Sistem Pendidikan Nasional. Diakses tanggal 5 Maret 2016 dari http://www.inherent-dikti.net/files/si sdiknas.pdf.

Kustawan, D. (2013) Manajemen Pendidikan Inklusi. Jakarta: Luxima.

Santrock, J.W. (2013). Psikologi Pendidikan buku 1 terjemahan Diana Angelica. Jakarta: Salemba Humanika.

Smith, J. D. (2006). Inklusi: Sekolah Ramah untuk Semua terjemahan Denis, Ny. Enrica. Bandung: Penerbit Nuansa. 